\title{
THE ROLE OF INNOVATION IN THE INTEGRATION PROCESSES OF INTEGRATED PROJECTS OF FOOD CHAIN: THE CASE OF THE CHERRY CULTIVATION CHAIN IN APULIA REGION ${ }^{1}$
}

\author{
Francesco CONTÒ, Mariantonietta FIORE, Piermichele LA SALA \\ University of Foggia, Department of Economics \\ Largo Papa Giovanni Paolo II, 71100, Foggia, Italy \\ francesco.conto@unifg.it, mariantonietta.fiore@unifg.it, piermichele.lasala@unifg.it \\ doi:10.13165/IE-13-7-4-05
}

\begin{abstract}
Innovation is one of the key strategies proposed in the literature and economic policies as a crucial driver of the agro-food sector. Innovation, especially in the agricultural sector, is not manifested only as an adoption of new technologies, but also requires a balance between new practices, techniques and alternative ways to organize and manage markets, labour, land tenure and distribution of benefits. In this context, the Economic Conventions (EC) have found fertile ground for coordination in the agro-food sector. Starting from a recent work by Malafaia et al. (2010) on the EC and the mechanisms of coordination, the paper analyzes the Integrated Projects of Food Chain (IPFs) approved by the Apulia region. The data collection was carried out through interviews and meetings with various actors in the supply chain and via Territory Listening Plane analysis, in order to identify the types of formalized or non formalized coordination, practiced by the agents. Further challenges are the definition and the identification of the forms of coordination set up by agents of the supply chains of IPFs via the implementation of the economic/computer/management model, which leads to the development of new business processes and to the validation of a prototype model of knowledge transfer and check-ups. In the end of the paper, conclusions are drawn.
\end{abstract}

JEL classification: L66.

Keywords: regulation, innovation, Economic Conventions (EC), agro-food chain, trust.

Reikšminiai žodžiai: reguliavimas, inovacijos, ekonominès konvencijos, žemės ūkio ir maisto grandinè.

\section{Introduction}

Innovation, especially in the agricultural sector, is not manifested only as the adoption of new technologies, but it also requires a balance between new practices,

1 The present paper has been designed and carried out within the following Integrated Project of Food Chain (IPF), Measure 124 of the Rural Development Programme of Apulia Region (EAFRD): Typical Cherry and Fruit. 
techniques and alternative ways to organize and manage markets, labour, land tenure, distribution of benefits, etc. An innovation system is a network of organizations, companies and individuals with the aim of bringing to market new products, new processes and new forms of organization, together with the government institutions and policies that influence the methods of action of the different agents of the supply chain. In the last twenty years, the food system has undergone significant changes that have given an increasingly central role to the studies of the production chain: such chain, in a broad sense, includes the 'network' of the main activities (and their main material and information flows), technologies, resources and organizations that contribute to the creation, processing, distribution, marketing and supply of a product and the whole series of checks on the origin and subsequent processing of a product that guarantee its validity by safeguarding midterm and final security. The change in perspective for the agro-food companies is to reconsider the skills and competitive advantage in view of the entire supply chain rather than a single stage, with consequences on the structure of the contractual relationships between the various actors and between those and the government regulation. The problem in the supply chain is bidirectional and has three critical dimensions: 'information asymmetry, incentive asymmetry, and arduous measurability' (Sporleder, 2011). In this context, the Economic Conventions (EC) have found fertile ground for coordination in the agro-food sector; this coordination is based on categorical characterizations of human beings in terms of identity, interest groups, whose habits comparison results in a variety of forms of coordination (Malafaia et al., 2010). The crisis of the model of perfect competition as an efficient mechanism of coordination between agents caused the application of the theory of the EC among the actors (Marescotti, 2000); in fact, the EC in the agro-food sector is gaining importance in the literature mainly for the influence studies of the French National Institute for Agricultural Research (INRA). The purpose of this paper is twofold: 1) to identify the forms of coordination of supply chains of agents configured by an Integrated Projects of Food Chain (IPF), seeking to develop quality plans and safety with the objective of generating competitive advantages in their respective markets, 2) to proceed to the definition of a model of integrated supply chain that should include innovations in production processes, support services and related economy and government in the New Economics of Food aspects. This model should govern the flow of information process/ product to qualify the production and direct markets, obtaining proper recognition in terms of image and added value. After a brief background literature on the crucial role of coordination and relationship, the paper focuses on data and methodology used, which is considered qualitative and experimental. Then, it analyzes the Integrated Project of Food Chain (IPF) approved by the Apulia Region - in Southern Italy - related to the cherry cultivation chain. The results and insight on coordination forms of the selected IPF are presented. Finally, an economic/computer/management model hypothesis is structured and conclusions are drawn. This approach was in a sense "seeking solution oriented", as the authors investigated this part of research in order to find and develop new business processes in the agro-food sector. So, this work can be considered a working in progress paper on the way of new lines of research and inquiry by depicting challenges and new opportunities. 


\section{Coordination, innovation and trust: A literature review}

Coase (1964) and Wolf (1979) made important contributions in the economic analysis of regulation in general, emphasizing the regulation of markets, which involves comparison and evaluation of imperfect alternatives. The economic literature highlighted that under certain circumstances the transaction costs and the coordination costs may counteract benefits deriving from economies of scale (Williamson, 1975) and specialization (Becker and Murphy, 1992), making adaptation strategies based on the exploitation of these benefits that are ineffective with respect to the objective of protection of farm incomes. Path-dependency forms of regional development of agricultural structures (Balmann, 1997) and in the coordination of the supply chain may be present, leading to different local optima (Huettel, 2009). Innovation is one of the key strategies proposed in the literature and economic government policies as a crucial driver of the agro-food sector (Alarcón and Sánchez, 2013; Opara, 2012; Bocchi, 2012). A research by Straete (2004) shown that a key role in boosting innovation and change in production systems are played by entrepreneurial skills and by the verticalization in the business integration: an example is Kazakhstan, where food industries are pursuing vertical integration strategies to address the chronic problems of the industry (Cormier, 2010). The innovative process is not based solely on the amount of R\&D produced by a company or investments that are directed to the modernization and strengthening of corporate structures (Spielman, 2006a and 2006b; Pardey et al., 2006); this perspective is absolutely biased. Sociological and management studies show that business innovation is not an individual act, but a social process, through which existing knowledge in different disciplines can cross and merge, creating new knowledge. In fact, several studies shown that innovation is a process based on interactions and exchanges of knowledge among a great diversity of stakeholders focusing on the role of social capital (Contò et al., 2012b). Over the last decades, studies have demonstrated the importance of system of innovation for business development (Lundvall, 1992; Freeman, 1991, 1995; Edquist and Johnson, 1997) and the positive influence of scientific networks (Callon, 1994; Coombs et al., 2003). The innovation is becoming more open or distributed over time (Coombs et al., 2003), in turn associated with increasing levels of collaboration and outsourcing (Chatterjee, 1996; Howells, 2006). The bonds that the company develops with the outer context generate new knock-on effects on the company's management.

The process of knowledge production is dynamic and cumulative over time, thanks to the mechanisms of interaction typical of an area characterized by a strong sense of belonging and strong relational synergies (Camagni, 1995). They encourage the introduction of new processes and products and decrease the uncertainty related to innovation in the agro-food system. Avermaete et al. (2004) and D'Alessio and Maietta (2007) showed that the main determinants of innovation are set up not only by investments in knowhow, but also by good partnerships with suppliers and customers. Further, complementarity of structural and relational governance is important (Gellynck and Kuhne, 2010) in order to segment the problems by sharing a common strategy. Building of strong partnerships fosters complementarities, setting specific targets that empower all rural stakeholders (Traore and Bickersteth, 2011) and structuring a better link between the formal 
and the informal systems (Okry et al., 2011) that could help to formulate a chain strategy and organization (Baars and Riediger, 2010). Structural governance (formalization) increases clarity and understanding about partners' differences, reduces uncertainty and increases rational commitment in uncertain and heterogeneous conditions.

Relational governance (trust) has a complementary role in this, because it requires time to develop trust in newly established innovation networks with limited previous cooperation. In addition to structural governance (rational commitment), relational governance (trust) is important to prevent attrition in the highly uncertain conditions (Tepic et al., 2011; Fischer et al., 2007). Several studies demonstrated positive and significant effect of relation goods (Bruni, 2007; Becchetti et al., 2007; Becchetti et al., 2006) that are local public goods co-produced and co-consumed by agents during their economic transactions (Guy, 2002).

Table 1. Order of values and of the worlds

\begin{tabular}{|l|l|l|l|l|l|l|l|}
\hline $\begin{array}{l}\text { Order of } \\
\text { the worlds }\end{array}$ & $\begin{array}{l}\text { Forms of } \\
\text { evaluation }\end{array}$ & $\begin{array}{c}\text { Informa- } \\
\text { tion } \\
\text { format }\end{array}$ & $\begin{array}{l}\text { Qualified } \\
\text { objects }\end{array}$ & $\begin{array}{l}\text { Elementary } \\
\text { relation }\end{array}$ & $\begin{array}{l}\text { Human } \\
\text { qualifi- } \\
\text { cation }\end{array}$ & Time & Space \\
\hline Market & Price & Monetary & $\begin{array}{l}\text { Products/ } \\
\text { services }\end{array}$ & Exchange & Interested & $\begin{array}{l}\text { Present, } \\
\text { short term }\end{array}$ & Global \\
\hline Industrial & $\begin{array}{l}\text { Producti- } \\
\text { vity }\end{array}$ & $\begin{array}{l}\text { Measurable } \\
\text { (statistics) }\end{array}$ & $\begin{array}{l}\text { Invest- } \\
\text { ments, } \\
\text { techniques, } \\
\text { methods }\end{array}$ & $\begin{array}{l}\text { Functional } \\
\text { link }\end{array}$ & $\begin{array}{l}\text { Professio- } \\
\text { nal, } \\
\text { ex pert }\end{array}$ & $\begin{array}{l}\text { Long term, } \\
\text { planned } \\
\text { future }\end{array}$ & $\begin{array}{l}\text { Cartesian } \\
\text { space }\end{array}$ \\
\hline Domestic & Reputation & $\begin{array}{l}\text { Oral, } \\
\text { exemplar }\end{array}$ & $\begin{array}{l}\text { Property, } \\
\text { specific } \\
\text { assets }\end{array}$ & Trust & $\begin{array}{l}\text { Trustwort- } \\
\text { hy }\end{array}$ & Habitual & $\begin{array}{l}\text { Polar: an- } \\
\text { chored on } \\
\text { proximity }\end{array}$ \\
\hline Opinion & Fame & Semiotic & $\begin{array}{l}\text { Media, } \\
\text { brands }\end{array}$ & $\begin{array}{l}\text { Recogni- } \\
\text { tion }\end{array}$ & Famous & Tendency & $\begin{array}{l}\text { Visibility } \\
\text { and } \\
\text { communi- } \\
\text { cation }\end{array}$ \\
\hline Civic & $\begin{array}{l}\text { Collective } \\
\text { interest }\end{array}$ & Formal & $\begin{array}{l}\text { Regula- } \\
\text { tions, } \\
\text { rights }\end{array}$ & Solidarity & $\begin{array}{l}\text { Represen- } \\
\text { tative }\end{array}$ & Stable & $\begin{array}{l}\text { Homoge- } \\
\text { neous }\end{array}$ \\
\hline Inspired & $\begin{array}{l}\text { Innovation, } \\
\text { creativity }\end{array}$ & Emotional & $\begin{array}{l}\text { Emotions } \\
\text { (artistic, } \\
\text { religious) }\end{array}$ & Passion & Creative & Rupture & Presence \\
\hline
\end{tabular}

Source: Malafaia et al., 2010

Normative resources, such as trust, allow reaching objectives and goals otherwise more difficult to achieve (Trigilia, 2001). Evaluation principles, called "order of values", constitute different forms of coordination also called "order of the worlds", refer to different principles of evaluation in order to determine actions (Malafaia et al., 2010). For Convention Economics, the logic of coordination is more open to uncertainties, critical tensions and creative arrangements than with ideas of a reproductive and stable order. Convention Economics identify six types of 'paths' directed to coordinate actions: in- 
spired, domestic, industrial, civic, market and opinion (Table 1). Domestic one, for example, has as form of evaluation of the reputation than Market path that has the price. Furthermore, for domestic path, trust is elementary relation and trustworthy is human qualification, while 'interested exchange' is the relation and qualification crucial for Market path. As it can be seen in Table 1, linking the order of the words with forms of evaluation, there is a sequence going from Market-Price binomial, passing through Industrial-Productivity, Domestic-Reputation, Opinion-Fame, Civic-Collective Interest to reach the Inspired-Innovation, Creativity binomial. The correlated elementary relations are exchange, functional link, trust, etc., until to passion that has an emotional information format. Qualified objectives are property and specific assets for Domestic path, but, as one can foresee, products/services are watchwords for Market path characterized by a global space and a monetary information format.

Generally, the reality and local context are crucial to define different forms: contracts (a discrete transaction between independent parties, enforced ultimately by recourse to the law) are the intermediary institution, through which markets and prevailing institutions influence each other (Figure 1) (Hubbard, 1997).

The 'New Institutional Economics' (NIE) focuses on property rights, conventions, authority structures and emerges from the theories of the firm (transaction costs), markets (imperfect information), politics (institutions used to favor interest groups) and history (institutional change).

Figure 1. Contracts as intermediaries between markets and prevailing institutions

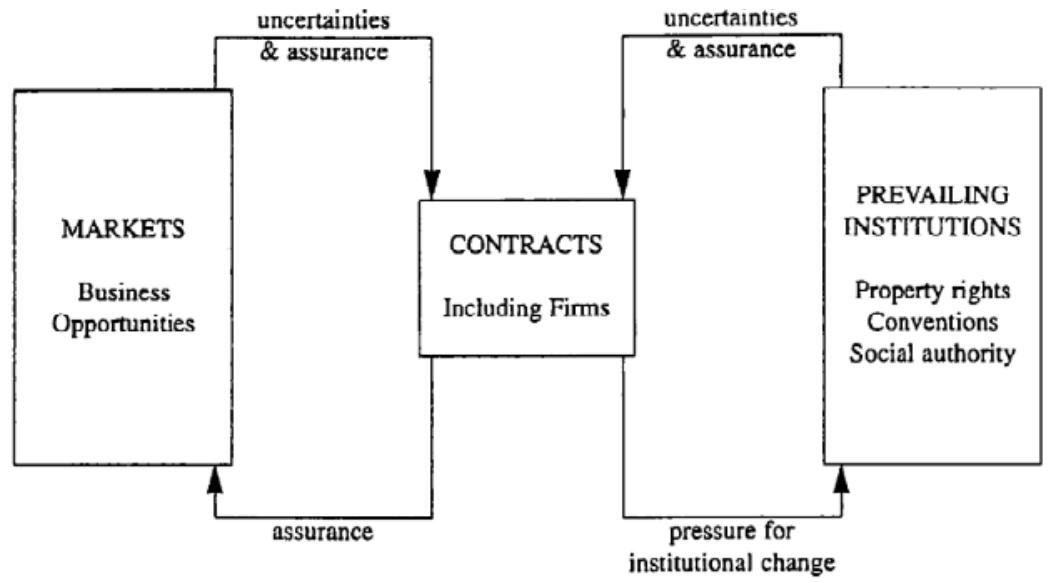

Source: Hubbard, 1997

Mechanical relation does not exist between transactions, contracts and prevailing institutions. Transaction is not discrete, not all contingencies can be predicted and performance cannot be continuously measured for real complexity and risky contracts (e.g., management contracts for large farms) (ibid.). 
Differently, as it can be seen in Table 1 and Figure 1, CE and NEI highlight two important concepts: (1) the need of building a problem solving relationship between principal and agent to spread risk and build trust (Hubbard, 1997); (2) the human beings are different and the parties are not independent, either because market power is unequal or social authority is unequal in terms of identity, interest groups, habits (Malafaia et al., 2010; Hubbart, 1997).

\section{Agricultural chains challenges}

According to the definition of the Ministry of Agriculture, Food and Forestry, the food supply chain is identified as all the stages of production, processing, marketing and distribution of agricultural and agro-food products (Contò, 2012a). This definition tends to favor the technical dimension of the supply chain to the detriment of aspects relating to the interdependence of organizations for the realization of a food product. The analysis of value chains is based on the recognition of a competitive edge for the benefit of organizations capable of developing supply chains through cooperative partnerships that reduce uncertainty by improving access to resources and overall efficiency. In this context, major investments and subsidies in research and transfer of innovation are very important, owing to their ability to influence the mechanisms and the overall value chain (EU, 2011). These are the results of specific policies developed at EU level, the weight of which, as demonstrated by the 2020 Strategy and the objectives of Horizon 2020, will be growing in the future development programs for the agricultural sector. In fact, research and the transfer of innovations in agriculture play a crucial role in development programs and future European strategies, for the competitiveness of companies and rural areas. The evolution of the agro-food system is strongly influenced by the evolution of consumer behaviour towards the product. The identification of all the companies involved in the process (from primary production, the processing, marketing) of a given article allows the consumer to recognize the responsibilities of all those, who contribute to the production of food, and to know the origin of all the raw materials that constitute the products, methods of production, the machine processes and the mode of transport adopted. In recent decades, consumers have proved to be sensitive not only to the nature of the products, but also for related services, such as easiness and fastness of their use, their maintenance, warranty of wholesomeness, quality, authenticity and certification of origin. In particular, with the increase of the internationalization of production and consumption of food, the changes move in two directions: 1) toward the consumer's needs at all stages of the supply chain and, in particular, towards reliable systems of food safety that provide the appearance competitive advantage, and 2) to the use of new information technologies: the combination and integration of agro-science and non-conventional technologies, such as sensors and computers, which provide new approaches to existing practices of business initiatives (Contò et al., 2010b). This evolution of the behaviour by consumers is generating a huge effort for companies in the food sector: the goal is to redraw the competitive environment and to rewrite the relations with the actors of the chain and the government institutions. 


\section{Materials and methods}

This work can be considered qualitative and experimental mainly due to the exploratory aspect of the theme of the EC, which is still relatively unexplored in the literature, as regards the empirical applications. Starting from a recent work of Malafaia et al. (2010) on the EC and the mechanisms of coordination, the paper analyzes as a case study 1 IPF approved by the Apulia region (Rural Development Programme 20072013 - Measure 124) in the cherry cultivation sector. This case study analysis has been selected since the paper's purpose is to deepen the ambit of decision and choices (Yin, 1994) among several steps of chain. The data collection was carried out through interviews with various actors in the supply chain, in order to identify the forms of coordination formalized or not, practiced by the agents of cherry cultivation sector. According to the logic of IPFs implementation, an asset of actors and structures that operate on the territory was elaborated, identifying the objectives, fields and methods of intervention, priorities and decision-making processes and was launched a collective dynamic of communication, thinking and discussion. The authors analyzed the 'IPF Territory Listening Plane, which lasted during the whole year 2012, according to a continuous path-way of information/communications. During seminars, meetings and briefings at different institutional and not forums, a data collection was carried out; by considering elements of analysis, specified and identified, a script argument has been made, without obeying a formal structure (Lakatos and Marconi, 2001). Even if one has a structured interview guide, this method of collection allows the freedom one needs for any situation (Malafaia et al., 2010) and for each different stage of the supply chain and in order to be able to obtain the information necessary for the scientific objective of the research work. Mode choice, given the type of agro-food 'players', was face-to-face meetings during agreed visits or in the above mentioned seminars, meetings, workshops. The average time of each interview was maximum 35-40 min to avoid the lack of interest and because the same agent was interviewed more than once. Specifically, the Fruit and Vegetables IPF, named "Typical Cherry and Fruit", has a structure made up of: $n$. 1 Association of producers; n. 35 Basic Producers; n. 13 transformation/processing firms; n. 3 Research Institutes (public and private); n. 1 Field pilot. So, 15 interviews were carried out with the agents of selected IPF:

- 7 Basic Producers (20\% of total number);

- 1 President of the Fruit and Vegetable Pos;

- 1 President of the Fruit and Vegetable Central;

- 1 President of the Consortium of Cherry;

- 2 transformation/processing firms;

- 1 Research Institute member;

- 1 LSD buyer;

- 1 buyer of the General Markets.

The producers' organizations (POs) are aggregations formed in order to concentrate supply and to commercialize the production of the members. In fact, PO includes the production of individual producers and members of the Fruit and Vegetable Central, which also deals with processing, packaging and logistics and sells to fruit and 
vegetable market and to supermarkets. Consortium of Cherry promotes the product and owns the brand Cherry, with which the PO trades and enhances marketing. In addition to the Fruit and Vegetable Central, the PO and the Consortium of Cherry, other agents are traders of fruit and vegetable markets selling to greengrocers, where the market operates (e.g., Bari, Milan, Turin, etc.). LSD buys and completes logistics distributing the product from the Distribution Centers to the individual stores and then sells to the final consumer. The transformation phase is limited, the cherry being a fresh product to be selected (calibrated), packaged and stored in cell until, it is transported to the vegetable market or the Distribution Center of retail. 1 LSD buyer and 1 buyer of the General Markets were interviewed in order to verify the level perception about the sector and the corresponding coordination level, thus matching results by different respondents.

Following the used approach of Malafaia et al. (2010), the choice criterion of sample representative in a qualitative research is not numeric, as is the case for quantitative research in order to allow the researcher to be capable of understanding the study object well. In fact, the actors selected here can be considered representative due to the fact that they present the same general characteristics of the population and have been strategic for obtaining the necessary information, having participated in the elaboration of the projects from the beginning. After the analysis of the results from the interviews, coordination characteristics output were described (Malafaia et al., 2010).

A second step of the paper was the definition and development of the model, following the need highlighted by the interviews analysis and by chain coordination issues. This model hypothesis considers two disciplines of research: the managerial-economic and management-information, arriving at a final model of integrated supply chain that is the synthesis.

\section{Typical Cherry and Fruit Chain: The analysis}

The fruit sector has a strong presence in the regional context. The cultivation of cherries in Apulia was, in 2010,35\% of the regional fruit UAA, compared to $5.57 \%$ of the national figure, and almost $1 \%$ of the UAA (Table 2).

Puglia region represents about $80 \%$ of the Italian offer of cherries. As with most of the agricultural products, the chain of cherry market sees Apulian producers in a position of absolute subjection to others in the chain represented by brokers, by exercising the activity of processing and packaging of cherries, retailers and distribution. Based on the data ISMEA-ACNielsen Homescan, a market share concentrated in the LSD equal to $80.1 \%$ in volume and $76.7 \%$ in value results with a growth in the last five years, respectively, of $3.8 \%$ and $4.3 \%$. The evolution of domestic demand in the medium term strongly penalizes the detail in the traditional fixed form, which stood at $11.3 \%$ of the shares. Such trends reflect changes in consumer and buying behavior of Italian families, mostly from the grocery sector (but also fresh) whose consumption habits have changed radically. 
Table 2. Relevance of cherry cultivation in Italy and Puglia (6th Agriculture Census ISTAT - 2010)

\begin{tabular}{|c|c|c|c|c|c|c|}
\hline \multirow[b]{2}{*}{ Indicator } & \multicolumn{3}{|c|}{2010 (CENSUS) } & \multicolumn{2}{|c|}{ UAA - 2008 (estimate) } & \multirow{2}{*}{$\begin{array}{c}\text { Variation } \\
\text { UAA } \\
2008 / 2010\end{array}$} \\
\hline & Italy & Puglia & $\begin{array}{c}\text { Incidence } \\
\text { of Puglia } \\
\text { on Italy }\end{array}$ & Italy & Puglia & \\
\hline Total UAA & 12.856 .047 & 1.285 .289 & $8,3 \%$ & - & - & - \\
\hline Fruit UAA & 424.303 & 35.228 & $10 \%$ & - & - & - \\
\hline $\begin{array}{l}\text { Cherry cultivation } \\
\text { UAA }\end{array}$ & 23.628 & 12.301 & $52,1 \%$ & 29.733 & 17.486 & $-29,65 \%$ \\
\hline $\begin{array}{l}\text { Incidence Cherry } \\
\text { cultivation on total } \\
\text { UAA }\end{array}$ & $0,18 \%$ & $0,96 \%$ & - & - & & - \\
\hline $\begin{array}{l}\text { Incidence Cherry } \\
\text { cultivation on fruit } \\
\text { UAA }\end{array}$ & $5,57 \%$ & $34,92 \%$ & - & - & - & - \\
\hline
\end{tabular}

Source: own processing on ISTAT data (2012)

The evolution of market shares in favor of the LSD (Large Scale Distribution) has greatly exacerbated the weakness of agricultural producers that currently are experiencing structural difficulties arising from a distribution system almost completely controlled by the LSD, downloading the lowering of revenues right on the part of the primary production chain. On the other hand, downstream of the industry, rather inexplicably consumer prices of agricultural products continue to rise or, at best, remain stable. The effect of the decrease in producer prices has now assumed structural levels that jointly increase inflationary costs of production. This generates a blow to the activity of the farmer. The average mark-ups of large retailers compared to the purchase price by the trader or by the Agricultural Cooperative settle between $70 \%$ and $120 \%$, reaching, in some cases, levels over $150 \%^{2}$ (ISMEA data).

A product is delivered to managers of large retailers as finished, chosen and put up in boxes. There are indiscriminately and without warning levels of reloading. The distribution of value in the supply chain is not, therefore, adequate, fair and transparent. A share of consumer price included between fifty and sixty remains the prerogative of the final distributor (LSD) and only a share included between forty and fifty is destined to all other parts of the sector (traders, processors, packers, brokers and farmers).

2 Enough to think that the demand for labor per hectare of specialized cherry production equals to approximately 600 hours, $85 \%$ of which are absorbed in the harvesting operations. Considering the provincial average of production of cherries and the average of labor productivity, amounting to $10-15 \mathrm{~kg} /$ hour/worker, it can be deduced that the annual requirement of manpower reaches 2.1 million work hours over a period of about two months. 


\section{Brief contextualization of Integrated Projects of Food Chain}

As derived by the literature review, vertical integration strategies and verticalization in the Business Integration (Straete, 2004; Cormier, 2010) can be a crucial driver in boosting innovation and change in food sector, increasing levels of collaboration (Coombs et al., 2003; Howells, 2006). Other side, Europe 2020 Strategy (2010a) and "CAP towards 2020" (2010b), identifies innovation crucial in order to face future challenges (Contò et al. 2013). In this context, Integrated Projects of Food Supply Chain (IFPs) fit well with these research and policy philosophy. IPFs are one implementation tool of the Rural Development Programme (RDP) of Apulia Region 2007-2013 (EAFRD resources) aimed at the involvement of a number of subjects within a specific chain, for the realization of individual investments, separate but coordinated between them, for the modernization of farms and processing facilities, the introduction of technological innovations to improve the quality, as well as the transfer of knowledge. IPFs are enabling an increase in added value for all segments of the supply chain and to take action strategies that improve the competitiveness of agricultural and agro-food sector, removing the critical issues of the sector and strengthening the individual sectors in the context of supply chain and with a view to integrated development (Contò et al., 2010a; 2010b). So, IPFs decline across sectors mainstreaming of regional planning as well as the national one, with the aim of responding in a systematic manner to specific needs expressed by operators of food chains. The design of supply chain aims to reduce and radicalize an important gap in terms of relationships and networks between supply chain operators. In fact, it aims to create new forms of governance aimed at the relationship of strategic alliances between economic operators and to improve the competitiveness and the overcoming of the main problems that characterize the sector (company size, concentration of supply, etc.). IPFs develop innovative initiatives for an integrated planning and develop technological and organizational innovation in order to increase the added value of food chains and allow adequate relapse on basic producers. With the establishment of the IPF, the goal is to strive to achieve a circuit, in which the strengthening of tangible and intangible assets would contribute to the consolidation of the agricultural sector, making it stable and in line with the new requirements of the market.

In operational terms, the IPF design is set up as a project presented by a partnership representing the interests and objectives of a plurality of subjects, in order to contribute to the full success of the initial target it takes a series of agreements and is a candidate to make investments through the use of the RDP measures. The establishment of a long-standing partnership between public and private actors contributes also to the creation of social overhead capital that boosts social cohesion, shared norms and values and generalized trust.

\section{The results by analysing in-depth interviews}

As it can be seen in the above Table 2, convention economics identifies the existence of six coordinate actions (Malafaia et al., 2010): inspiration, domestic, industrial, 
civic, market and opinion corresponding to respective six forms of coordination, also called "order of worlds" moving actions. The results based on in-depth interviews with selected agents identified the forms of prevalent coordination, such as a particular mixture among civic, domestic and market. The analysis of the interviews conducted with representatives of the various stages of the cherry supply chain revealed important relational characteristics and types of coordination based on relations and so on 'cooperative trust'. Results by most of the interviews ( 9 out of 15 respondents) highlight that the Typical Cherry and Fruit chain is quite complex to analyze because each product can be considered to be a finished product (fresh or dried), intended for the consumer market and a raw material for the processing industry, manipulation and transformation. Furthermore, producers' respondents ( 7 out of 15 respondents) focus on the 'high variability of production, the wide choice of variety, type of plant and, consequently, the methods of crop and agricultural practices, making the sector extremely diverse and managerially complex. The farm is, therefore, sure in a more predominant than other supply chains, the fulcrum within the flow diagram of the production chain that reaches the consumer. The interactions that occur upstream of the production process profoundly affect on the guarantee and protection of the health of the final product. The use of plant protection products both in terms of the types and in the methods of use and the choice of planting material (seedlings, cuttings, etc.) are critical points upstream in the supply chain that necessarily require attention, professional training and coordination.

Sales are carried out mainly relating to verbal agreements both for not conditioned fresh bulk products (63\% of the cases), either for the conditioned products $(67 \%)$. In the case of firms selling by subscribing contracts, the duration is predominantly annual, with renegotiation of the terms of maturity. For setting the price, operators are mostly based on negotiations between the parties: the sale price is fixed, in most cases (51\%), based on the prices of the main markets (local, national or foreign) and, for another $26 \%$, based on the settlement price of the membership structure to which the company sells its product (cooperative, association, consortium, PO).

Among the major factors, which affect the selection of suppliers, the compliance to specific quality standards was the one most widely shared by $74 \%$ of the respondents that supply fresh fruit and $50 \%$ of those that supply semi fruit. This phenomenon is found particularly in the case of IPFs companies, which make use of disciplinary supply, based primarily on requirements related to product characteristics and product certification (organic, PDO/PGI). Another important factor that affects the choice of suppliers is the price level, as stated by $42 \%$ of the respondents, who buy fresh fruit, and $45 \%$ of those, who buy fruit semi finished.

In terms of market outlets, the supply chain shows a remarkable variability since it is very common in this sector direct contact producer-consumer as they are well-established supply relationships, direct or through intermediaries, with the agri-food supply chains. Throughout all steps of the supply chain, elementary relations are driven by exchange, trust and solidarity, linked respectively to market, domestic, civic, such as the order of the worlds (Table 1). Downstream of the chain coordination is based on market and price relations, so on short term with coherence predominant order and products/service, such as qualified objectives: human qualification is interested not pro- 
fessional/expert. Upstream, between producers and Fruit and Vegetable POs or Fruit and Vegetable Central, coordination is structured on strong assets and on personal trust relationship between chain agents that is stable and longstanding. Coordination form is oral (verbal agreements) and coordination space is polar, anchored on both 'geographical and reputation' proximity. Trust is light motif of the prevalent coordination forms. The need of building a strong relationship between principal and agent to spread risk and build trust because market power is unequal or social authority is unequal in terms of identity, interest groups, habits, revealed to be crucial by the respondents in line with that in theory advocated (Malafaia et al., 2010; Hubbart, 1997). Civic coordination emerges via common solidarity representing a homogeneous stable space direct to collective interests based on rights and regulations (Consortium of Cherry). Finally, chain agents deliberate about quality using civic interests as reference, such as the environment or the protection of a sector or region (Malafaia et al., 2010). The case of the IPF in Cherry cultivation sector demonstrates that a mix of 'order of the worlds' deriving by combinations of Market/ Domestic/Civic coordination is present; this special and 'undefined' asset is suggestive of IPFs planning 'philosophy' aiming at the establishment and creation of social overhead capital that boosts social cohesion, shared norms and values and generalized trust.

\section{The hypothesis of composite model and expected results}

At this point, a model is defined in order to proceed to the definition of a coordination model of integrated supply chain that should include innovations in production processes, support services and related economic and government in the New Economics of Food aspects. This model should govern the flow of information process/ product to qualify the production and direct markets, obtaining proper recognition in terms of image, added value and well defined coordination form. The model proposed will facilitate the dissemination and the design of digital and technological innovations aimed at the integration of the agro-food sector in the New Economics of Food, pursuing the following objectives: facilitating companies' access to digital systems integration; defining and delivering experimental support services in the areas of process/product, market, technology, training and promotion of culture district; encouraging the creation and consolidation of an information network among the main stakeholders in the sector, aimed at supporting the sharing of best practices on management and technology.

Related to the axis computer-management and considered the first part of the analysis based on the EC, patterns of development and functional type should be taken into account, which can promote collaborative arrangements between the different actors in the chain. The theoretical approach used is based on the digital market place, in order to pursue the strengthening of relations between producers, suppliers and distributors overcoming the geographical boundaries of time and rationalization of logistics. Furthermore, the model develops a full and profitable exploitation of the opportunities arising from the globalization of niche markets and an increase in the quantity and quality of the information made available by ICT tools and their use to provide value-added services, related to the traceability of the product and its typicality. However, with regard 
to the economic-management axis, through the instrument of the check-up, the authors mean to achieve the return of the strategic framework of their members in order to develop a process of development and business innovation, in which there are fully defined methods and ways of knowledge transfer to increase the managerial culture of entrepreneurs and support services to establish the dimension in every reality the strategic path that the project intends to follow, especially as regards the economic aspects of the processes (Contò et al., 2010b). Figure 2 below shows the general structure of the model.

Figure 2. Axes structure of model: computer-management and economic-management

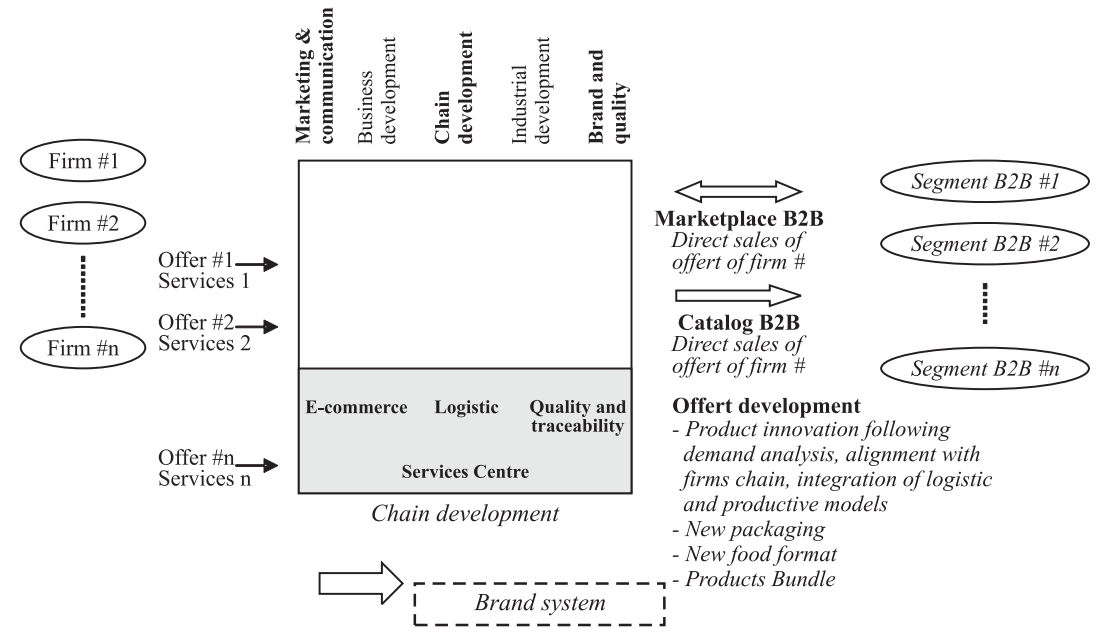

Source: own processing

It is expected that the definition and identification of the forms of coordination set up by agents of the supply chains of IFPs with the implementation of the economic model/computer/management leads to the following:

1. Development of new business processes of Economics of Food, aiming at a significant improvement of services and the effectiveness of production processes;

2. Feasibility study for the construction of a reference database and the relevant validation of a prototype model of knowledge transfer;

3. Implementation of a methodology for the realization of check-ups, with subsequent processing of the same.

Ultimately, this will mean for all companies, which are active in the supply chain, to obtain various services related mainly to the following two categories: information services, designed to provide information and news relating to innovation, the trend of the industry, market trends, along with other information to support the development of business processes, e-business, to support companies in the management of specific business processes and to encourage interaction and coordination between businesses 
in the food industry, both regionally and nationally and internationally, the traceability throughout all stages of the food chain, regardless of the number of steps and operators of which they are composed linked by general trust. Step by step and from chain actor to following chain actor, trust is as a binary relation: borrowing a computer science model by Ray and Chakraborty (2004), coordination form based on trust defining a normalized trust relationship can be formalized:

$$
-(A \stackrel{c}{\longrightarrow} B) \frac{N}{t} \text {. }
$$

It specifies A's normalized trust on B at a given time $\mathrm{t}$ for a particular chain $\mathrm{c}$. The value of a trust relationship is denoted by the following expression:

$$
\mathbf{v}(A \stackrel{c}{\longrightarrow} B) \frac{N}{t} .
$$

The value of a trust relationship is a vector of numbers and is a number in $[-1 ;+1]$ that is associated with the normalized trust relationship. Each element in the trust vector represents a parameter that contributes towards the trust value. Each experience that can influence the degree of trust can be interpreted as either a trust-positive experience or a trust-negative experience. A trust-positive experience contributes towards a gain in trust degree, whereas a trust-negative experience contributes towards a loss in trust degree. Thus:

$$
v_{k_{i}}=\left\{\begin{array}{lll} 
& \text { where: } \\
-1, \text { if } e_{k_{i}} \in \mathrm{P} & v_{k_{i}} \text { is the weight of the } k^{\text {th }} \text { event in the } i_{k_{i}} \in \mathrm{Q} \text { interval; } & \mathcal{E}=\{\mathrm{P} \cup \mathrm{Q}\} ; \\
& \mathrm{P} \text { denotes the set of all trust-positive events; } \\
& \text { Q denotes the set of all trust-negative events. (3) }
\end{array}\right.
$$

A weight of +1 is assigned if an event is in the set $\mathrm{P}$ and -1 if the event is in the set $\mathrm{Q}$; 0 if the trust value does not change relation between $A$ and $B$ that is constrained for institutional or sectorial reasons. Five different parameters can be identified, influencing trust values positively or negatively: (1) reputation and knowledge [bad; good]; (2) common goal sharing [yes; no]; (3) rights and regulations [yes; no]; (4) known experiences [good; bad]; (5) context and sector [important; not important]. These parameters are crucial in order to analyze how trust can change over time chain coordination form. Authors' further studies are examining new grounds to determine and calculate these parameters that in this time represent an easy formalization of a trust model to be adapted to chain coordination. A lot of work remains to be done.

\section{Conclusions}

Challenge and new opportunities for the agro-food sector are driven by two key words: innovation and trust. Innovation is one of the key strategies proposed in the lit- 
erature and in economic policies as a crucial driver of the agro-food sector. Trust is the key to allow reaching objectives and goals otherwise more difficult to reach. Convention Economics and New Institutional Economics highlight the need of building trust (Hubbard, 1997), given inequality of market power or social authority in terms of identity, interest groups, habits (Malafaia et al., 2010; Hubbart, 1997). In this context, the Integrated Projects of Food Chain (IPFs) may be the operational tool for the implementation of the integrated approach of rural development. The case study analyzed of Apulian IPF in Cherry cultivation sector demonstrates that a mix of 'order of the worlds' deriving by combinations of Market/Domestic/Civic coordination forms is present; this special and 'undefined' asset is suggestive of IPFs planning 'philosophy', aiming at the establishment and creation of social overhead capital that boosts social cohesion, shared norms and values and generalized trust. In fact, by means of the steps of the supply chain, elementary relation is driven by exchange, trust and solidarity. IPFs represent the possibility of undertaking a path of innovative development at the local level, in order to start investing on intangible resources, on people, on their wealth of expertise and networks of relationships.

A model governing the flow of information process/product can qualify the production and direct markets, obtaining proper recognition in terms of image, added value and well defined coordination form. This model facilitates the dissemination and the design of digital and technological innovations aimed at the integration of the agro-food sector in the New Economics of Food. It facilitates the access of the companies to the digital systems integration and encourages the creation and consolidation of an information network among the main stakeholders in the sector, aimed at supporting the sharing of best practices on management. Furthermore, the first step to build a trust model to be adapted to chain coordination represents an attempt to formalize trust and trust value in a chain model. This approach was in a sense 'seeking solution oriented', as this part of research was investigated in order to find and develop new business processes and paths in the agro-food sector starting from coordination form. So, this work can be considered a working in progress paper on the way of new lines of research and inquiry by depicting challenges and new opportunities. Further studies are paving the way for new perspectives.

\section{References}

1. Alarcón, S.; Sánchez, M. Business Strategies, Profitability and Efficiency of Production. Spanish Journal of Agricultural Research. 2013, 11(1): 19-31.

2. Avermaete, T.; Viaene, J.; Morgan, E. J.; Pitts, E.; Crawford, N.; Mahon, D. Determinants of Product and Process Innovation in Small Food Manufacturing Firms. Trends Food Science \& Technology. 2004, 14: 474-483.

3. Baars, E.; Riediger, A. A Market Analysis of the Somali Banana Sector and Its Potential for Export Revival: Experiences of Support to Agricultural Marketing Services and Access to Markets (SAMSAM) Project. Acta Horticulturae. 2010, 879: 811-818. 
4. Balmann, A.; Dautzenberg, K.; Happe, K.; Kellermann, K. On the Dynamics of Structural Change in Agriculture. Internal Frictions, Policy Threats and Vertical Integration. Outlook on Agriculture. 2006, 35, 2: 115-121.

5. Becchetti, L.; Londo Bedoya, D.A.; Trovato, G. Income, Relational Goods and Happiness. Departmental Working Papers, Tor Vergata University, CEIS. 2006, 227.

6. Becchetti, L.; Perroni, A.; Rossetti, F. Sociability and Happiness. Working Paper, Università di Bologna-AICCON. 2007, 44.

7. Becker, G.S.; Murphy, K.M. The Division of Labor, Coordination Costs, and Knowledge. Chicago: University of Chicago, Economics Research Center, 1991.

8. Bocchi, S.; Christiansen, S.; Oweis, T.; Porro, A.; Sala, S. Research for the Innovation of the Agro-food System in International Cooperation. Italian Journal of Agronomy. 2012, 7(3): 262-273.

9. Bruni, L. La ferita dell'altro. Economia e relazioni umane. Trento: Il Margine, 2007.

10. Callon, M. Is Science a Public Good? Science, Technology and Human Values. 1994, 19: 395-424.

11. Camagni, R. Global Network and Local Milieu: Applying the Gremi Approach to Urban Evolution. Révue deconomie régionale et urbaine. 1995, 3: 591-606.

12. Camagni, R. The Concept of Innovative Milieu and Its Relevance for Public Policies in European Lagging Regions. In K. Haynes, K. Button and P. Nijkamp (eds.). Regional Dynamics. Vol. II. Cheltenham: Edward Elgar, 1996, p. 269-292.

13. Chatterjee, D. Accessing External Sources of Technology. Research Technology Management. 2006, 39(2): 48-56.

14. Coase, R. Discussion. American Economic Review. 1964, 54(3): 194-219.

15. Contò, F.; Fiore, M.; La Sala, P.; De Lucia, C. Renewable Energy from Biomass and Innovation Opportunities: A European Innovation Partnership (EIP) Approach. 21th Biomass EU BC\&E Conference Proceedings. Copenhagen, 3-7 June, 2013.

16. Contò, F.; Fiore, M.; La Sala, P. Organization and Structure of the Chain in Integrated Projects for the Food Chain in the Region of Basilicata: The Effects on the New Rural Dynamics. PAGRI/IAP. 2012a, 3: 77-85.

17. Contò, F.; Fiore, M.; La Sala, P. The Cross Border Cooperation Programs: Human Capital and Relational Capital. Timişoara Journal of Economics and Business. 2012b, 5(18).

18. Contò, F.; La Sala, P.; Papapietro, P. The Metapontum Agro-Food District of Quality: An Innovative Model of Governance for Local Development trough Informatics. In: Andreopoulou, Z. Agricultural and Environmental Informatics, Governance, and Management: Emerging Research Applications. Thessaloniki: Information Science Reference, 2010a.

19. Contò, F.; La Sala, P.; Papapietro, P. Rural Development in the Area of Pollino: Integrated Design of an "Atypical" Chain. In: 118th EAAE Seminar "Rural Development: Governance, Policy Design and Deliver". Bled, 25-27/08/2010, University of Ljubljana, Leibniz Institute of Agricultural Development in Central and Eastern Europe (IAMO), and the Slovene Association of Agricultural Economists (DAES), $2010 \mathrm{~b}$.

20. Coombs, R.; Harvey, M.; Tether, B. Distributed Processes of Provision and Innovation. Industrial and Corporate Change. 2003, 12: 1051-1081. 
21. Cormier, K. Settling Expectations in Kazakhstan's Agriculture Sector. NCEEER Working Paper. 2010.

22. D’Alessio, M.; Maietta, O. W. Le determinanti delle innovazioni di prodotto nell'industria alimentare italiana: il ruolo dell'Università e delle istituzioni pubbliche di ricerca. Wp n. 4, Dipartimento di Economia e Politica Agraria, CFEPSR, Università degli Studi di Napoli, Federico II, 2007.

23. Edquist, C.; Johnson, B. Institutions and Organizations in Systems of Innovation. In Edquist, C. (ed.). Systems of Innovation: Technologies, Institutions, Organizations. Pinter, London: Pinter, 1997, p. 41-63.

24. European Commission. Proposal for a Council Decision establishing the Specific Programme Implementing Horizon 2020 - The Framework Programme for Research and Innovation (2014-2020). COM (2011) 811 final, Brussels, 2011.

25. European Commission. Communication from the European Commission, Europe 2020: A Strategy for Smart, Sustainable and Inclusive Growth. COM 2020, 2010a.

26. European Commission. Communication from the European Commission, The CAP towards 2020. COM 672, 2010b.

27. Fischer, C.; Gonzalez, M.; Henchion, M.; Leat, P. Trust and Economic Relationships in Selected European Agri-food Chains. Food Economics. 2007, 4(1): 40-49

28. Freeman, C. Networks of Innovators: A Synthesis of Research Issues. Research Policy. 1991, 20: 499-514.

29. Freeman, C. The National Innovation Systems in Historical Perspective. Cambridge Journal of Economics. 1995, 19(1).

30. Gellynck, K.; Kuhne, B. Horizontal and Vertical Networks for Innovation in the Traditional Food Sector. International Journal on Food System Dynamics. 2010, 1(1).

31. Gui, B. Più che scambi incontri. La teoria economica alle prese con i fenomeni Relazionali. In Sacco, P.L. and Zamagni S. (eds.). Complessità relazionale e comportamento economico. Materiali per un nuovo paradigma di razionalità. Bologna: Il Mulino, 2002.

32. Hohn, H.W.; Lutz, S. Contingencies of Innovative Networks: A Case Study of Successful Interfirm R\&D Collaboration. Research Policy. 1994, 23: 47-66.

33. Howells, J. Intermediation and the Role of Intermediaries in Innovation. Esrc Centre for Research in Innovation and Competition (Cric), Institute of Innovation Research, University of Manchester, 2006.

34. Hubbard, M. The 'New Institutional Economics' in Agricultural Development: Insights and Challenges. Journal of Agricultural Economics. 1997, 48(2): 239-249.

35. Huettel, S.; Margarian, A. Structural Change in the West German Agricultural Sector. Agricultural Economics. 2009, 40(1): 759-772.

36. ISTAT. 6th Agriculture Census ISTAT. Roma, 2010.

37. Lakatos, E.M.; Marconi, M. Metodologia do trabalho científico. São Paulo: Atlas, 2001.

38. Lundvall, B. National Systems of Innovation: Towards a Theory of Innovation and Interactive Learning. London: Pinter Publishers, 1992.

39. Malafaia, G.C.; Barcellos, G.O.J.; Pedrozo E.A.; Camargo, M.E. Journal of Development and Agricultural Economics. 2010, 2(3): 178-187.

40. Marescotti, A. Marketing Channels, Quality Hallmarks and the Theory of Conventions. In: Sylvander, B.; Barjolle, D.; Arfini, F. (eds.). The Socio-economics of 
Origin Labelled Products in Agro-food Supply Chains: Spatial, Institutional and Coordination Aspects. INRA, Serie Actes et Communications, n.17-2, Paris, 2000, p.103-122 (67th EAAE Seminar, Le Mans (France), 28-30 October 1999.

41. Okry, F.; Van Mele, P.; Nuijten, E.; Struik, P.C.; Mongbo, R.L. Organizational Analysis of the Seed Sector of Rice in Guinea: Stakeholders, Perception and Institutional Linkages. Experimental Agriculture. 2011, 47(1): 137-157.

42. Opara, U.L. The Need for a Professional Network of Agricultural and Biosystems Engineers in Africa. International Journal of Postharvest Technology and Innovation. 2012, 2(4): 426-432.

43. Pardey, G.P.; Alston, J.M.; Piggott, R.R. Agricultural R\&D in the Developing World: Too Little, too Late. Washington D.C.: International Food Policy Research Institute (IFPRI), 2006.

44. Ray, I.; Chakraborty, S. A Vector Model of Trust for Developing Trustworthy Systems. Lecture Notes in Computer Science (including subseries Lecture Notes in Artificial Intelligence and Lecture Notes in Bioinformatics). 2004, 3193: 260-275.

45. Spielman, D. J. A Critique of Innovation Systems Perspectives on Agricultural Research in Developing Countries. Innovation Strategy Today. 2006a, 2(1): 41-54.

46. Spielman, D. J. Systems of Innovation: Models, Methods, and Future Directions. Innovation Strategy Today. 2006b, 2(1): 55-66.

47. Sporleder, T. L.; Boland, M. A. Exclusivity of Agri-food Supply Chains: Seven Fundamental Economic Characteristics. International Food and Agribusiness Management Review, International Food and Agribusiness Management Association (IAMA). 2011, 14(5).

48. Stræte, E. P. Innovation and Changing 'Worlds of Production': Case-studies of Norwegian Dairies. European Urban and Regional Studies. 2004, 11(3): 227-241.

49. Tepic, M.; Omta, O.; Trienekens, J.; Fortuin, F. The Role of Structural and Relational Governance in Creating Stable Innovation Networks: Insights from Sustainabilityoriented Dutch Innovation Networks. Journal on Chain and Network Science. 2011, 11(3): 197-211.

50. Traore, A.; Bickersteth, S. Addressing the Challenges of Agricultural Service Provision: The Case of Oxfam's Strategic Cotton Programme in Mali. International Journal of Agricultural Sustainability. 2011, 9: 82-90.

51. Trigilia, C. Social Capital and Local Economic Development. European Journal of Social Theory. 2011, 4: 427-442.

52. Williamson, O.E. The Economics of Organization: The Transaction Cost Approach. American Journal of Sociology. 1981, 87(3): 548-577.

52. Wolf, C. A Theory of Non-Market Failure: Framework for Implementation Analysis. Journal of Law and Economics. 1979, 21(1): 107-139.

54. Yin, R. Case Study Research: Designs and Methods. 6th. ed. London: SAGE Publications, 1994. 


\section{INOVACIJŲ VAIDMUO INTEGRUOTŲ MAISTO GRANDINĖS PROJEKTŲ INTEGRAVIMO PROCESUOSE: VYŠNIŲ KULTIVAVIMO GRANDINĖS APULIJOS REGIONE ATVEJIS}

Santrauka. Inovacijų skatinimas yra viena pagrindinių žemės ūkio ir maisto sektoriaus plètros strategijų, pateikiamų literatūroje bei ekonomikos politikoje. Inovacijomis žemès ūkyje laikoma ne tik naujų technologijų i̦sisavinimas, bet ir naujų geros praktikos pavyzdžių, alternatyvių rinkos organizavimo ir valdymo metodų taikymas, tinkamas darbo išteklių, žemès ir kitų gerybių paskirstymas. Šiame kontekste ekonominès konvencijos (EK) yra koordinavimo žemès ūkio sektoriuje pagrindas. Neseniai atliktoje EK ir koordinavimo mechanizmų studijoje (Malafaia et al. 2010) išnagrinèti integruoti maisto grandinès projektai (IMGP), patvirtinti Apulijos regione. Duomenys buvo surinkti interviu būdu bei suorganizavus ịvairius suinteresuotųjų asmenų maisto grandinèje atstovus siekiant nustatyti formalizuoto ir neformalizuoto koordinavimo tipus tarp šioje grandineje veikiančių agentų. Kitas svarbus iššǔkis, analizuojamas šiame straipsnyje, yra nustatyti ir identifikuoti koordinavimo formas IMGP tiekimo grandineje igyvendinant ekonominị kompiuterinị valdymo modelị, kuris leidžia iggyvendinti naujus verslo procesus bei ịvertinti modelio validumą žinių perdavimui ir patikrinimui.

Francesco CONTÒ - Full professor, Department of Economics, University of Foggia (Italy). Research fields: innovation and competitiveness in agro-food system, food innovation, health food innovation and management, rural development and multifunctionality.

Francesco CONTÒ - Ekonomikos katedros profersorius, mokslų daktaras, Foggia universitetas, Italija. Mokslinių interesų sritis: inovacijos ir konkurencingumas žemès ūkio ir maisto sistemose, maisto naujovès, sveiko maisto inovacijos ir valdymas, kaimo plètra ir daugiafunkciškumas.

Mariantonietta FIORE - Ph.D., Research Fellow, Department of Economics, University of Foggia (Italy). Research fields: vertical coordination in agro-food systems, sustainable development, agricultural policy and food chain, survey method, econometrics models.

Mariantonietta FIORE - Ekonomikos katedros mokslų daktarè, Foggia universitetas, Italija. Mokslinių tyrimų sritys: žemės ūkio ir maisto sistemų vertikalus koordinavimas, darnus vystymasis, žemès ūkio politika maisto tiekimo grandinèje, apklausos metodai, ekonometriniai modeliai.

Piermichele LA SALA - Ph.D., Research Fellow, Department of Economics, University of Foggia (Italy). Research fields: rural development policies, agro-food districts, integrated projects of food chain, innovation in agro-food chain.

Piermichele LA SALA - Ekonomikos katedros mokslų daktaras, Foggia universitetas, Italija. Mokslinių tyrimų sritys: kaimo plètros politika, žemès ūkio ir maisto rajonai, integruoti projektai maisto grandinèje, inovacijos žemès ūkio maisto produktų grandinèje. 